\title{
Antifungal activity using medicinal plant extracts against pathogens of coffee tree
}

SILVA, J.L. "; SOUZA, P. E.'; MONTEIRO, F. P.'; FREITAS, M. L. O.'; SILVA JÚNIOR, M. B.'; BELAN, L. L. ${ }^{1}$ 'Universidade Federal de Lavras (UFLA), Câmpus Universitário, Caixa Postal 3037, CEP 37200-000, Lavras, Minas Gerais, Brasil. * jhonlemos1990@gmail.com

\begin{abstract}
Generally, the medicinal plants have antifungal substances that can be used for the plant protection against phytopathogens. The objective of this study was to know the efficiency of aqueous extracts from medicinal plants against the major etiological agents of coffee tree. The aqueous extracts used were extracted from bulbs of Allium sativum, leaves of Vernonia polysphaera, Cymbopogon citratus, Cymbopogon nardus, Cordia verbenacea, Eucalyptus citriodora, Ricinus communis, Azadirachta indica, Piper hispidinervum and flower buds of Syzygium aromaticum. The etiological agents considered for this study were Cercospora coffeicola, Colletotrichum gloeosporioides, Fusarium oxysporum, Phoma tarda, Rhizoctonia solani and Hemileia vastatrix. The screening for harmful extracts was done based on mycelial growth and conidial germination inhibition. All experiments performed were in vitro conditions. The inhibition of mycelial growth was performed mixing the extracts with the PDA. This mixture was poured in Petri dishes. On the center of the dishes was added one PDA disc with mycelium. It was incubated in a chamber set to $25^{\circ} \mathrm{C}$. The evaluation was done daily by measuring the mycelial growth. The germination assessment was also performed with Petri dishes containing agar-water medium at $2 \%$. These were incubated at $25^{\circ} \mathrm{C}$ for 24 hours. After this period the interruption of germination was performed using lactoglycerol. The experiments were conducted in a completely randomized design. The most effective plant extracts against the micelial growth and conidial germination were V. polysphaera, S. aromaticum and A. sativum.
\end{abstract}

Keywords: Phoma tarda, Cercospora coffeicola, Colletotrichum gloeosporioides, Hemileia vastatrix, Phytopathology.

RESUMO: Atividade antifúngica utilizando extratos de plantas medicinais contra fitopatógenos do cafeeiro. Geralmente, as plantas medicinais têm substâncias antifúngicas que podem ser utilizadas para a proteção das plantas contra fitopatógenos. O objetivo deste estudo foi conhecer a eficiência de extratos aquosos de plantas medicinais contra os principais agentes etiológicos do cafeeiro. Os extratos aquosos utilizados foram extraídos de bulbos de Allium sativum, folhas de Vernonia polysphaera, Cymbopogon citratus, Cymbopogon nardus, Cordia verbenacea, Eucalyptus citriodora, Ricinus communis, Azadirachta indica, Piper hispidinervum e botões florais de Syzygium aromaticum. Os agentes etiológicos considerados neste estudo foram Cercospora coffeicola, Colletotrichum gloeosporioides, Fusarium oxysporum, Phoma tarda, Rhizoctonia solani e Hemileia vastatrix. A triagem dos extratos foi realizada com base no crescimento micelial e na inibição da germinação de conídios. Todos os experimentos foram realizados em condições in vitro. A inibição do crescimento micelial foi realizada misturandose os extratos com PDA. Esta mistura foi vertida em placas de Petri. No centro das placas foi adicionado um disco de PDA com micélio. Incubou-se em câmara programada para $25^{\circ} \mathrm{C}$. A avaliação foi feita diariamente através da medição do crescimento micelial. $O$ experimento sobre a germinação também foi realizado com placas com meio ágar-água a $2 \%$. Estas foram incubadas durante 24 horas. Após este período, a interrupção da germinação foi realizada utilizando lactoglicerol. Os experimentos foram conduzidos em delineamento inteiramente casualizado. Os extratos de plantas mais eficazes contra o crescimento micelial e germinação de conídios foram V. polysphaera, S. aromaticum e A. sativum.

Palavras-chaves: Phoma tarda, Cercospora coffeicola, Colletotrichum gloeosporioides, Hemileia vastatrix e Fitopatologia.

Recebido para publicação em 16/10/2012

Aceito para publicação em 26/03/2014 


\section{INTRODUCTION}

Coffee (Coffea arabica L.) is an important revenue source to Brazil, which stands out as the world's largest producer and exporter of the grain. According to the National Supply Company (2013) the production of coffee cultivar Arabica in Brazil at 2011 was 50.83 million bags. Among the variable elements that affect yield, diseases represent one of the most limiting factors for the production and productivity of coffee plants, both for small farmers family-based as for enterprise-scale producers (Ferrao et al., 2007).

The disease control of coffee plants has been managed primarily with fungicides. This practice in the plant protection presents itself as an attractive alternative, due its simplicity of implementation, economy, effectiveness and also by the satisfactory results in short time. However, the use of pesticides for plant disease control has promoted several environmental problems as contamination as natural source (food, soil, water, animals, and the poisoning of farmers). The appearance of resistant populations, emergence of iatrogenic diseases, reduction of beneficial organisms and biodiversity was also reported (Morandi \& Bettiol, 2009).

In recent years, there has been increasing interest in farming methods that are environmentally and economically viable. Studies have shown that oils and extracts of leaves of some plant are efficient in controlling plant diseases (Pereira et al., 2008). This control can be achieved by direct fungitoxic action of active compounds. These substances can inhibit the mycelial growth or spore germination and trigger the resistance induced by physiological changes in the plant, such as induction of pathogenesis-related enzymes, lignifications and phytoalexins (Stangarlin et al., 1999; Schwan-Estrada \& Stangarlin, 2005).

These substances extracted from plants are cheaper than fungicides, readily available to the farmers and exhibit low human toxicity and risks of environmental pollution. In many instances, it could be obtained at the farm itself (Martinez, 2002). All these attributes make these alternative products perfectly adapted to the holistic approach of biodynamic agriculture and organic food (Betti et al., 2009). Additionally, while conventional coffee producers have a wide range of chemicals to control pests and diseases in crops, the options available to organic farmers who apply organic production systems are reduced and little studied.

Some published studies emphasizes the existence of bioactive substances in plant extracts, which control the pathogenic fungi in coffee plant such as Phoma sp. (Barguil et al., 2005), Cercospora coffeicola Berk. \& Cooke., (Santos et al., 2007) and Hemileia vastatrix Berk. \& Br. (Santos et al., 2007). It also works in the same way with others fungus, for instance, the use of aqueous extract of Syzygium aromaticum L. inhibited the mycelial growth of Aspergillus sp., Penicillium sp., Colletotrichum sp., Fusarium solani Snyd \& Hans, Cercospora kikuchii (Mats. \& Tomoy.) Gardner. and Phomopsis sp. (Venturoso et al., 2011). Souza et al. (2007) reported that Allium sativum $\mathrm{L}$. and Cymbopogon citratus Stapf. extracts inhibited the germination of Fusarium proliferatum Matsush. Bastos (1997) demonstrated in vitro and in vivo the inhibitory action of the essential oil of Piper aduncum L. against Moniliophtora perniciosa (Stahel) Singer (etiologic agent of witch's broom on Theobroma cacao L.).

Based on this features the objective of this study was to evaluate the antifungal activity of aqueous crude extracts from Allium sativum L., Azadirachta indica Juss., Cordia verbenacea DC., Cymbopogon citratrus DC., Cymbopogon nardus Rendle, Eucalyptus citriodora Hook., Ricinus communis L., Piper hispidinervum DC., Syzygium aromaticum Perry, Vernonia polysphaera Baker on the fungus Cercospora coffeicola Berk. \& Cooke, Colletotrichum gloeosporioides Penz, Fusarium oxysporum Schlecht, Phoma tarda (Stewart) Verm., Rhizoctonia solani Kühn. and Hemileia vastatrix Berk \& Br.

\section{MATERIAL AND METHODS}

The experiments were conducted in the second half of 2012 at the Federal University of Lavras - UFLA. All experiments were repeated twice to support the results. The plants were collected in the Medicinal Plants Garden of UFLA. Lavras city is situated in the state of Minas Gerais at latitude

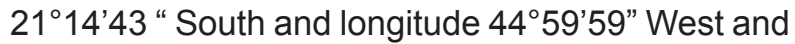
an altitude of 919 meters. The statistical procedure was randomized design with three replications, ten treatments and two controls.

The extracts were obtained from $A$. sativum bulbs, leaves of $V$. polysphaera, $C$. citratus, $C$. nardus, $C$. verbenacea, E. citriodora, $R$. communis, $A$. indicates, $P$. hispidinervum and flower bud of $S$. aromaticum.

The material was washed with distilled water and disinfested with sodium hypochlorite at $0.5 \%$ for 30 minutes to remove microorganisms present on its surface. Thereafter, it was washed threefold with distilled water to remove the hypochlorite. Then it was dried on paper towels for 24 hours. After, it was subjected to grinding in a knife mill. The crushed powder was employed to obtain the aqueous extract by adding $80 \mathrm{~g}$ of material in one liter of distilled water (a crude extract of $80 \%$ ). It was incubated in dark chamber set to $25^{\circ} \mathrm{C}$ for 24 hours. After this time the crude extract was filtered using two sterile 
gauze. The liquid extract was storage at $4^{\circ} \mathrm{C}$ until it be used. For $A$. sativum and $S$. aromaticum were collected $80 \mathrm{~g}$ of plant material. It was crushed in blender with $100 \mathrm{~mL}$ of distilled water and prepared according to the methodology described above for the other extracts.

The pathogens isolated from coffee plants were $P$. tarda, C. coffeicola, C. gloeosporioides, $R$. solani, and $F$. oxysporum. It was cultivated in Petri dishes containing PDA (Potato - Dextrose - Agar) culture medium. All fungus were incubated for seven days in a growth chamber at $25^{\circ} \mathrm{C} \pm 2$ and 12 hours of photoperiod.

The effect over mycelial growth was performed with discs (10 $\mathrm{mm}$ in diameter) containing mycelia. It was deposited with its upper portion down in the center of Petri dishes (90 mm in diameter) containing a mixture of PDA medium and plant extract at a concentration of $20 \%$.

As a negative control was used Petri dishes with PDA without extracts and as a positive control was used a strobilurin (picoxystrobina) and triazole (cyproconazole) at the concentration indicated by the manufacturer $\left(2.25 \mu \mathrm{l} . \mathrm{L}^{-1}\right)$. The plates were carefully sealed, identified and incubated in a growth chamber at $25^{\circ} \mathrm{C}$ with a photoperiod of 12 hours. The evaluations were performed by daily measurements of the colonies (average of two measurements diametrically opposite). It was started 24 hours after the incubation and continued until the mycelium take $2 / 3$ of the surface on the culture medium in one of the treatments.

The spores germination was also evaluated. Spore suspensions of the fungi $P$. tarda, C. gloeosporioides, and $F$. oxysporum were obtained from fungus cultivated on PDA at $25^{\circ} \mathrm{C}$ and $12 \mathrm{~h}$ of photoperiod. The spore liberation was performed adding $10 \mathrm{~mL}$ of sterile distilled water plus Tween 20 ( $1 \mathrm{drop} / 10 \mathrm{~mL}$ distilled water) on the surface of the fungus culture. Drigalski spreader was employed to release the spores. A sterilized gauze was used to remove the mycelium. The spore concentration was adjusted to $1.5 \times 10^{5}$ conidia/mL with the hemacytometer.

The C. coffeicola spores were obtained according to Pereira et al. (2008). This method use naturally infected leaves from coffee trees subjecting them to a moist chamber for three days. The scraping of conidia produced was performed with a soft bristle brush dampened with distilled water. The suspension obtained was filtered through two gauzes and the concentration was adjusted to $1.5 \times 10^{4}$ conidia. $\mathrm{mL}^{-1}$.

For the inoculum of $H$. vastatrix naturally infected leaves of coffee plants were collected in the experimental field of the UFLA Agriculture Department. Urediniospores were removed from leaves using a soft bristle brush. An urediniospores suspension of $H$. vastatrix was prepared with distilled water containing Tween $80(0,025 \%)$.

The experiment was performed using Petri dishes with agar-water medium at $2 \%$. It was added $1 \mathrm{~mL}$ of extract at $20 \%$ to the medium surface. The conidial suspension was also added and spreaded over the medium. The dishes were incubated in a chamber set to $25^{\circ} \mathrm{C}$ and dark for $H$. vastatrix and photoperiod of $12 \mathrm{~h}$ for the other fungi. After 24 hours was proceeded the interruption of germination using lactoglycerol.

The evaluation was made by counting the number of spores germinated and not germinated. The plate was divided into four quadrants and 50 spores per quadrant was counted resulting in 400 spores for each treatment. The germinated conidia was that one which showed the germination tube measuring twice the diameter of the spore. As a control was used $1 \mathrm{~mL}$ of distilled water (negative control) and $1 \mathrm{~mL}$ of the fungicide in the same previous dose (positive control).

Data were subjected to analysis of variance with SISVAR 4.0 (Ferreira et al., 2011), when it was significant by $f$ test, means were compared by the Scott Knott test at $5 \%$ probability.

\section{RESULTS AND DISCUSSION}

\section{Influence of extracts on the mycelial growth of etiologic agents}

The plant extracts suppressed the mycelial growth (Table 1). The extracts of $A$. sativum, $V$. polysphaera and $S$. aromaticum reduced the mycelial growth of $F$. oxysporum by $100 \%$ compared to the control. Amaral \& Bara (2005) showed that rhizome extract of Curcuma longa L. at $1 \%$ repressed the mycelial growth of $F$. oxysporum and $R$. solani in $61.15 \%$ and $61.1 \%$, respectively. Cunico et al. (2004) using as raw material the ethanolic extract of the roots $(0.204 \mathrm{mg} / \mathrm{mL})$ and stems $(2.670 \mathrm{mg} / \mathrm{mL})$ of Ottonia martiana Miq. observed a mycelial inhibition of $F$. oxysporum in $62.30 \%$ and $55.74 \%$, respectively.

The mycelial growth of $P$. tarda was reduced $100 \%$, when extracts from $A$. sativum, $V$. polysphaera, C. nardus and S. aromaticum were used. Information about the control of this fungus by plant extracts is scarce in the literature and thus little is known about their reaction to these compounds.

The extracts more efficient on the control of C. gloeosporioides were A. sativum, V. polysphaera and S. aromaticum. Ribeiro \& Bedendo (1999) observed a reduction of $67.57 \%$ in mycelial growth working with $A$. sativum extract at $1 \%$. Rozwalka et al. (2008) observed that C. gloeosporioides can be affected by aqueous extracts of Rosmarinus officinalis L., Zingiber officinale Rosc., Chamomila 
recutita L. and S. aromaticum at a concentration of $10 \%$ with $50.57 \%, 64.37 \%, 73.56 \%$ and $100 \%$ of mycelial growth inhibition.

For $C$. coffeicola the reduction of mycelial growth was $64.48 \%$, when extracts of $A$. sativum, V. polysphaera and S. aromaticum were applied. Chalfoun et al. (2009) observed a reduction of $5.05 \%$ on the mycelial growth of C. coffeicola, when $10 \mu \mathrm{L}$ of methanol extract of $C$. longa was applied on top of the disk that contained the fungus. By using the extracts of $A$. sativum, V. polysphaera, $C$. nardus and $S$. aromaticum against $R$. solani was observed a mycelial growth inhibition of $100 \%$. The different results obtained using several species as biofungicides extracts suggests that there are many substances, which can still be exploited for the management of plant pathogens.

\section{Influence of the extracts on the spores germination from etiologic agents in coffee trees The plant extracts also suppressed the}

conidial germination (Table 2). For $H$. vastatrix the most effective treatments were $A$. sativum, $C$. nardus, $C$. citratus and $V$. polysphaera. It has been reported the action of these extracts on the spores germination in other fungi. The studies of Ke-Qiang \& van Bruggen (2001) and Wang et al. (2001) reported the inhibition of $100 \%$ on the zoospores formation of Phytophthora infestans (Mont.) de Bary using the A. sativum extract.

For C. gloeosporioides the most efficient extract in the conidial germination were $A$. sativum and $V$. polysphaera. Hernández-Albíter et al. (2007) reported the ineffectiveness of $C$. citratus and $A$. indica extracts on the conidial germination of two C. gloeosporioides strains. This difference may be attributed to the methodology used in each case.

For $F$. oxysporum and $C$. coffeicola the best extracts were $C$. aromaticum and $A$. sativum. Alam et al. (2002) working with $A$. indica reported that only $33 \%$ of conidia from F. oxysporum were germinated after contact with the extract for 30 minutes. Cogo

Table 1. Inhibition of mycelial growth of coffee plant pathogens affected by different herbal extracts at concentration of $20 \%$.

\begin{tabular}{llllll}
\hline Treatment & F. oxysporum & P. tarda & C. gloeosporioides & C. coffeicola & R. solani \\
\hline A. sativum & $100.00 \mathrm{f}$ & $100.00 \mathrm{f}$ & $100.00 \mathrm{e}$ & $100.00 \mathrm{e}$ & $100.00 \mathrm{~g}$ \\
V. polysphaera & $100.00 \mathrm{f}$ & $100.00 \mathrm{f}$ & $100.00 \mathrm{e}$ & $100.00 \mathrm{e}$ & $100.00 \mathrm{~g}$ \\
C. citratus & $19.77 \mathrm{~b}$ & $46.22 \mathrm{c}$ & $17.04 \mathrm{~b}$ & $62.00 \mathrm{~b}$ & $61.83 \mathrm{e}$ \\
C. nardus & $49.28 \mathrm{~d}$ & $100.00 \mathrm{f}$ & $59.22 \mathrm{~d}$ & $78.55 \mathrm{~d}$ & $100.00 \mathrm{~g}$ \\
S. aromaticum & $100.00 \mathrm{f}$ & $100.00 \mathrm{f}$ & $100.00 \mathrm{e}$ & $100.00 \mathrm{e}$ & $100.00 \mathrm{~g}$ \\
C. verbenacea & $31.99 \mathrm{c}$ & $56.69 \mathrm{~d}$ & $50.28 \mathrm{c}$ & $71.83 \mathrm{c}$ & $72.19 \mathrm{f}$ \\
E. citriodora & $59.65 \mathrm{e}$ & $70.64 \mathrm{e}$ & $65.64 \mathrm{~d}$ & $75.70 \mathrm{c}$ & $28.70 \mathrm{~b}$ \\
R. communis & $30.85 \mathrm{c}$ & $37.21 \mathrm{~b}$ & $45.53 \mathrm{C}$ & $60.71 \mathrm{~b}$ & $48.52 \mathrm{~d}$ \\
A. indica & $36.89 \mathrm{c}$ & $62.21 \mathrm{~d}$ & $58.10 \mathrm{~d}$ & $79.84 \mathrm{~d}$ & $38.16 \mathrm{C}$ \\
P. hespidinervum & $56.19 \mathrm{~d}$ & $67.44 \mathrm{e}$ & $46.37 \mathrm{c}$ & $73.64 \mathrm{c}$ & $33.73 \mathrm{C}$ \\
Control & $00.00 \mathrm{a}$ & $0.00 \mathrm{a}$ & $0.00 \mathrm{a}$ & $0.00 \mathrm{a}$ & $0.00 \mathrm{a}$ \\
Fungicide & $100.00 \mathrm{f}$ & $100.00 \mathrm{f}$ & $100.00 \mathrm{~d}$ & $100.00 \mathrm{e}$ & $100.00 \mathrm{~g}$ \\
\hline
\end{tabular}

Means followed by the same letter in the column do not differ by the Scott Knott test at $5 \%$ probability. Data are presented in percentage.

Table 2. Germination of spores of the coffee plant pathogens under different plant extracts at a concentration of $20 \%$.

\begin{tabular}{|c|c|c|c|c|c|}
\hline Treatment & H. vastatrix & C. gloeosporioides & F. oxysporum & C. coffeicola & P. tarda \\
\hline A. sativum & $0.00 \mathrm{a}$ & $4.25 \mathrm{a}$ & $0.00 \mathrm{a}$ & $0.00 \mathrm{a}$ & $14.17 \mathrm{~b}$ \\
\hline V. polysphaera & $8.00 \mathrm{a}$ & $6.75 \mathrm{a}$ & $20.25 b$ & $20.25 b$ & $26.25 c$ \\
\hline C. citratus & $3.25 \mathrm{a}$ & $39.50 \mathrm{~b}$ & $64.75 \mathrm{c}$ & $72.25 \mathrm{~d}$ & $32.50 \mathrm{~d}$ \\
\hline C. nardus & $2.00 \mathrm{a}$ & $77.25 \mathrm{e}$ & $55.25 \mathrm{c}$ & $63.00 \mathrm{c}$ & $87.08 \mathrm{~h}$ \\
\hline S. aromaticum & $0.00 \mathrm{a}$ & $0.00 \mathrm{a}$ & $7.75 \mathrm{a}$ & $0.00 \mathrm{a}$ & $19.17 b$ \\
\hline C. verbenacea & $35.00 \mathrm{~b}$ & $70.50 \mathrm{~d}$ & $88.75 \mathrm{~d}$ & $77.75 \mathrm{e}$ & $47.92 \mathrm{e}$ \\
\hline E. citriodora & $55.25 \mathrm{c}$ & $65.75 \mathrm{c}$ & $66.00 \mathrm{c}$ & $66.00 \mathrm{~d}$ & $15.42 b$ \\
\hline R. communis & $33.75 b$ & $80.00 \mathrm{e}$ & $86.00 \mathrm{~d}$ & $86.00 \mathrm{e}$ & $76.67 \mathrm{~g}$ \\
\hline A. indica & $36.50 \mathrm{~b}$ & $61.75 \mathrm{c}$ & $80.25 \mathrm{~d}$ & 80.25 e & $80.83 \mathrm{~g}$ \\
\hline P. hespidinervum & $42.75 b$ & $71.00 d$ & $56.75 \mathrm{c}$ & $56.75 \mathrm{c}$ & $68.75 \mathrm{f}$ \\
\hline Fungicide & $1.25 \mathrm{a}$ & $0.00 \mathrm{a}$ & $1.50 \mathrm{a}$ & $1.51 \mathrm{a}$ & $0.00 \mathrm{a}$ \\
\hline Control & $68.50 \mathrm{~d}$ & $82.75 \mathrm{e}$ & $92.50 \mathrm{~d}$ & $90.00 \mathrm{e}$ & $92.08 \mathrm{i}$ \\
\hline
\end{tabular}

Means followed by the same letter in the column do not differ by the Scott Knott test at $5 \%$ probability. Data are presented in percentage. 
et al. (2011) observed that, when the extract of A. sativum was applied in coffee seedlings was achieved a reduction of $20.8 \%$ of the disease after 75 days of inoculation with C. coffeicola. These studies reinforce the potential of plant extracts in diseases control. The conidial germination inhibition of $P$. tarda (Stewart) Verm. was most affected by $C$. nardus, $A$. indica and $R$. communis.

\section{Control of mycelial growth by plant extracts considering the pathogens complex in coffee trees}

When seeking for a new substance to control pathogens a wide spectrum of control is important for taking action controlling several plant pathogens. The extracts that inhibited the mycelial growth of all fungi were $V$. polysphaera, $S$. aromaticum and $A$. sativum. Because of this satisfactory results, they outstand as a promising extracts to screening for strong antifungal compounds. Sehajpal et al. (2009) classified the activity of $A$. sativum as strong by verifying the magnitude of $R$. solani mycelial growth inhibition working with the concentrations at 300 , 500 and $1000 \mathrm{ppm}$.

The other extracts had different levels of control and their practical use must be targeted to specific pathogens. Suwitchayanon \& Kunasakdakul (2009) observed changes on the hyphae of $F$. oxysporum, when treated with the extract of $S$. aromaticum at $1900 \mathrm{ppm}$. Aye \& Matsumoto (2011) working with $R$. solani reported the inhibition in 87.5 and $100 \%$ of the mycelial growth, when applied extracts from the leaves of $A$. indica and $S$. aromaticum, respectively.

Inhibition of conidial germination by plant extracts considering the pathogens in coffee tree

Due the effect of the extracts on the conidial germination and also for the particular behavior of each fungus is suggested a direct spray to use these extract as a common practice. The most efficient extract and uniform considering the complex of pathogens were $A$. sativum and $C$. citratus, which presented an excellent control for $H$. vastatrix and C. gloeosporioides. Ogbebor et al. (2007) reported a complete inhibition on the conidial germination of C. gloeosporioides with Allium sativum at 10, 25, 50 and $100 \%$, highlighting the potential of this extract for agricultural use.

For the aqueous extract of E. citriodora, although it has not had satisfactory results was reported by Celoto et al. (2008) that the hydroethanolic extract derived from this plant inhibited more than $90 \%$ of spores germination from C. gloeosporioides.

\section{CONCLUSIONS}

The plant extracts that better controlled the mycelial growth considering all fungi were $A$. sativum, V. polysphaera and S. aromaticum.

The plant extracts that better controlled the conidial germination considering all fungi were $A$. sativum, S. aromaticum and V. polysphaera.

\section{ACKNOWLEDGE}

We are thankful to the National Council for Scientific and Technological Development (CNPq) for the scholarship provided.

\section{REFERENCE}

ALAM, S.; AKHTER, N.; BEGUM, F.; BANU, M. S.; ISLAM, M. R.; CHOWDHURY, A. N.; ALAM, M. S. Antifungal activities (in vitro) of some plant extracts and smoke on four fungal pathogens of different hosts. Pakistan Journal of Biological Sciences, v. 5, n. 3, p. 307-309, 2002.

AMARAL, M. F. Z. J.; BARA, M. T. F. Avaliação da atividade antifúngica de extratos de plantas sobre o crescimento de fitopatógenos. Revista Eletrônica de Farmácia, v. 2, n. 2, p. 5-8, 2005.

AYE, S. S.; MATSUMOTO, M. Effect of some plant extracts on Rhizoctonia spp. and Sclerotium hydrophilum. Journal of Medicinal Plants Research, v. 5, n. 16, p. 3751-3757, 2011.

BASTOS, C. N. Efeito do óleo de Piper aduncum sobre Crinipellis perniciosa e outros fungos fitopatogênicos. Fitopatologia Brasileira, v. 22, p. 441-443, 1997.

BARGUIL, B. M.; RESENDE, M. L. V.; RESENDE, R. S.; BESERRA JÚNIOR, J. E. A.; SALGADO, S. M. L. Effect of extracts from citric biomass, rusted coffee leaves and coffee berry husks on Phoma costaricencis of coffee plants. Fitopatologia Brasileira, v. 30, p. 535-537, 2005.

BETTI, L.; TREBBI, G.; MAJEWSKY, V.; SCHERR, C.; SHAH-ROSSI, D.; JÄGER, T.; BAUMGARTNER, S. Use of homeopathic preparations in phytopathological models and in field trials: a critical review. Homeopathy, v. 98, p. 244-266, 2009.

CELOTO, M. I. B.; PAPA, M. de F. S.; SACRAMENTO, L. V. S. do; CELOTO, F. J. Antifungal activity of plant extracts to Colletotrichum gloeiosporioides. Acta scientiarum, v. 30, n. 1, p. 1-5, 2008.

CHALFOUN, S. M.; OLIVEIRA, D. F.; SOUZA, L. P.; BOTELHO, D. M. S.; PEREIRA, M. C.; MACIEL, W.; CARVALHO, D. A. Seleção de extratos vegetais para controle da cercosporiose do cafeeiro. In: VI SIMPÓSIO DE PESQUISA DOS CAFÉS DO BRASIL, 6, 2009, Vitória. Anais... Vitória: EMBRAPA-CAFÉ, 2009, p. 399. COGO, F. D.; CORREA, A.; FERNANDES, L. G.; CARVALHO, H. P.; CAMPOS, K. A. Eficiência de extratos vegetais no controle de cercosporiose em mudas de cafeeiro. Tecnologia \& Ciência Agropecuária, v. 5, n. 1, p. 31-34, 2011.

COMPANHIA NACIONAL DE ABASTECIMENTO. Acompanhamento da safra brasileira: café, quarto 
levantamento. Brasília: Conab, 20p. 2013.

CUNICO, M. M.; CARVALHO, J. L. S.; SILVA, V. C.; MONTRUCCHIO, D. P.; KERBER, V. A.; GRIGOLETTI JÚNIOR, A.; AUER, C. G.; MIGUEL, M. D.; MIGUEL, O. G. Avaliação antifúngica de extratos obtidos de Ottonia martiana Miq. (piperaceae) sobre três fitopatógenos. Arquivos do instituto biológico, v. 71 (supl.), p. 1-749, 2004.

FERRAO, R. G. (Org.); FONSECA, A. F. A. (Org.); BRAGANCA, S. M. (Org.); FERRAO, M. A. G. (Org.); DE MUNER, L. H. (Org.). Café Conilon. 1. ed. Vitoria, ES: Incaper, 702 p., 2007.

FERREIRA, D. F. Sisvar: a computer statistical analysis system. Ciência e Agrotecnologia, v. 35, n. 6, p. 1039-1042, 2011.

FERREIRA, D. F. Análises Estatísticas por meio do Sisvar para Windows 4.0. In: REUNIÃO ANUAL DA REGIÃO BRASILEIRA DA SOCIEDADE INTERNACIONAL DE BIOMETRIA, 45, 2000, São Carlos. Anais... São Carlos: UFSCAR, p. 255- 258. 2000.

HERNÁNDEZ-ALBÍTER, R. C.; BARRERA-NECHA, L. L.; BAUTISTA-BAÑOS, S.; BRAVO-LUNA, L. Antifungal potential of crude plant extracts on conidial germination of two isolates of Colletotrichum gloeosporioides (Penz.) Penz. and Sacc. Revista Mexicana de Fitopatologia, v. 25, p. 180-185, 2007.

KE-QIANG, C.; VAN BRUGGEN, A. H. C. Inhibitory efficacy of several plant extracts and plant products on Phytophthora infestans. Journal of Agricultural University of Hebei, v. 24, p. 108-116, 2001.

MARTINEZ, S. S. O Nim - Azadirachta indica: natureza, usos múltiplos, produção. Londrina: Instituto Agronômico do Paraná, 2002, 142 p.

MORANDI, M. A. B.; BETTIOL, W. Controle Biológico de Doenças de Plantas no Brasil. In: BETTIOL, W.; MORANDI, M. A. B. (Org.). Biocontrole de Doenças de Plantas: uso e perspectivas. Jaguariúna-SP: Embrapa Meio Ambiente, 2009 p. 7-14.

OGBEBOR, N. O.; ADEKUNLE, A. T.; ENOBAKHARE, D. A. Inhibition of Colletotrichum gloeosporioides (Penz) Sacc. causal organism of rubber (Hevea brasiliensis Muell. Arg.) leaf spot using plant extracts. African Journal of Biotechnology, v. 6, n. 3, p. 213-218, 2007.

PEREIRA, R. B.; ALVES, E.; RIBEIRO JÚNIOR, P. M.; RESENDE, M. L. V.; LUCAS, G. C.; FERREIRA, J. B. Extrato de casca de café, óleo essencial de tomilho e acibenzolar-S-metil no manejo da cercosporiose-docafeeiro. Pesquisa Agropecuária Brasileira, v. 43, p.
1287-1296, 2008.

RIBEIRO, L. F.; BEDENDO, I. P. Efeito inibitório de extratos vegetais sobre Colletotrichum gloeosporioides - agente causal da podridão de frutos de mamoeiro. Scientia Agricola, v. 56, n. 4, 1999.

ROZWALKA, L. C.; LIMA, M. L. R. Z. C.; MIO, L. L. M.; NAKASHIMA, T. Extratos, decoctos e óleos essenciais de plantas medicinais e aromáticas na inibição de Glomerella cingulata e Colletotrichum gloeosporioides de frutos de goiaba. Ciência Rural, v. 38, n. 2, p. 301307, 2008.

SANTOS, F. S.; SOUZA, P. E.; RESENDE, M. L. V.; POZZA, E. A.; MIRANDA, J. C.; RIBEIRO JÚNIOR, P. M.; MANERBA, F. C. Efeito de extratos vegetais no progresso de doenças foliares do cafeeiro orgânico. Fitopatologia Brasileira, v. 32, p. 59-63, 2007.

SCHWAN-ESTRADA, K. R. F.; STANGARLIN, J. R. Extratos e óleos essenciais de plantas medicinais na indução de resistência. In: CAVALCANTI, L. S.; DI PIERO, R. M.; CIA, P.; PASCHOLATI, S.F.; RESENDE, M. L. V.; ROMEIRO, R.S. (Ed.). Indução de resistência em plantas a patógenos e insetos. Piracicaba: FEALQ, 2005, p.125-138.

SEHAJPAL, A.; ARORA, S.; KAUR, P. Evaluation of plant extracts against Rhizoctonia solani causing sheath blight of rice. The Journal of Plant Protection Sciences, v. 1, n. 1, p. 25-30, 2009.

SOUZA, A. E. F.; ARAÚJO, E.; NASCIMENTO, L. C. Atividade antifúngica de extratos de alho e capim-santo sobre o desenvolvimento de Fusarium proliferatum isolado de grãos de milho. Fitopatologia Brasileira, v. 32, n. 6, p. 465-471, 2007.

STANGARLIN, J. R.; SCHWAN-ESTRADA, K. R. F.; CRUZ, M. E. S.; NOZAKI, M. H. Plantas medicinais e controle alternativo de fitopatógenos. Biotecnologia Ciência e Desenvolvimento, v. 11, p. 16-21, 1999.

SUWITCHAYANON, P.; KUNASAKDAKUL, K. In vitro effects of clove and turmeric extracts controlling crucifer pathogens. Journal of Agricultural Technology, v. 5, n. 1, p. 193-199, 2009.

VENTUROSO, L. R.; BACCHI, L. M. A.; GAVASSONI, W. L. Atividade antifúngica de extratos vegetais sobre o desenvolvimento de fitopatógenos. Summa Phytopathologica, v. 37, n. 1, p. 18-23, 2011.

WANG, S.; WANG, X.; LIU, J.; CAO, K. Screening of Chinese herbs for the fungitoxicity against Phytophthora infestans. Journal of Agricultural University of Hebei, v. 24, p. 101-107, 2001. 